ВОРЖЕЦОВ Александр Григорьевич - доктор философских наук, профессор кафедры государственного, муниципального управления и социологии Казанского национального исследовательского технологического университета (420015, Россия, Республика Татарстан, г. Казань, ул. К. Маркса, 68; vag41@list.ru)

\title{
ЗАКОНЧИЛИСЬ ЛИ РЕВОЛЮЦИИ 1917 г. В РОССИИ?
}

Аннотация. В статье рассматриваются последствия Февральской и Октябрьской революций 1917 г. в России, даются оценки позиции российских ученых и политиков по особенностям этих революций. В статье автор попытался ответить на дискуссионный вопрос: «Закончились ли Февральская и Октябрьская революции 1917 г. в России?»

Ключевые слова: Февральская революция, Октябрьская революция, демократическая революция в СССР и России в конце 1980-х - начале 1990-х гг., Конституция РФ, новая демократизация российского общества

$\Phi$ евральская и Октябрьская революции 1917 г. в России стали предметом оживленной дискуссии ученых-обществоведов в год столетнего юбилея. Однако до сих пор среди исследователей нет единства в понимании сущности этих революций. Поэтому следует продолжить обсуждение проблем Февральской и Октябрьской революций.

В этом плане заслуживает внимание постановка Е.М. Кожокиным дискуссионного вопроса: «Завершилась ли революция у нас в стране?» По его мнению, «Великая русская революция 1917 года... изменила в стране, казалось, все - государственное устройство, экономическую систему, идеологию, искусство». А «в 1991 году вновь произошла полная смена исторических декораций». И «мы расстались с государственной системой, стержнем, несущей конструкцией которой была коммунистическая партия». И значит, «вопрос о революции закрыт!» [Кожокин 2017: 110]. Во-первых, возникает ряд вопросов к названию статьи. Почему речь идет о русской революции, а не российской? Ведь ее участниками были представители разных народов, а русские в то время составляли $44 \%$ всего населения страны. И почему речь идет об одной Великой революции 1917 г. - Октябрьской? Ведь более адекватным было бы назвать две революции - Февральскую и Октябрьскую? А разве можно назвать октябрьский переворот $^{1}$ «великой революцией», если, по выражению автора, «партия большевиков в итоге получила власть, а миллионы, желавшие мира и земли, обрели гражданскую войну, нищету и страдания еще больше, чем в царскую эпоху» [Кожокин 2017: 117].

По мнению И.К. Пантина, «о Февральской революции, ее характере и противоречиях в нашей литературе говорят в положительном плане». Она реально «осуществила то, чего добивались демократические и либеральные силы российского общества в революции 1905-1907 годов - свержение самодержавия, установление демократической формы правления». И «более того, на время Россия стала самой свободной страной в мире» [Пантин 2015: 244]. Во-вторых, вызывает сомнение вывод автора, что «против самодержавного государства успешно могла бороться только вождистская партия» [Кожокин 2017: 120]. На самом деле Февральская революция привела к свержению самодержавия и образованию Временного правительства, которое состояло из представителей

\footnotetext{
${ }^{1}$ Сами большевики до 1927 г. называли революцию октябрьским переворотом.
} 
разных либеральных и социалистических партий (кадеты, эсеры, меньшевики). А в октябре 1917 г. Временное правительство состояло только из представителей социалистических партий (эсеры и меньшевики).

В-третьих, на наш взгляд, следует уточнить вывод автора, что необходимо говорить «о монархизме как особой форме персонификации власти в одном лице», т.к. «революция... не уничтожила монархизм как феномен политической культуры» [Кожокин 2017: 120]. Дело в том, что после Февральской революции монархисты потерпели полный крах. По мнению В.П. Булдакова, «императора никто не поддержал, включая церковь, официальным главой которой он считался» [Февральская революция... 2007: 5]. Поэтому можно сказать, что Февральская революция практически уничтожила монархизм и как феномен политической культуры. А вот самовластие как особая форма персонализации власти в одном лице оказалось более живучим в нашей стране. На протяжении XX в. следует выделить три формы самовластия: самодержавие, советскую форму, президентскую форму. В рамках этих форм необходимо выделить «жесткие» и «мягкие» варианты их реализации. А после «мягких» вариантов самовластия в нашей стране наступали периоды демократизации. Так было в период с Февральской до Октябрьской революции 1917 г. Так было и в период с конца 80-х и до начала 90-х гг. XX в. В настоящее время функционирует «мягкий» вариант президентской формы самовластия.

В-четвертых, трудно согласиться с выводом автора, что «революция во всех ее ипостасях в России завершена» [Кожокин 2017: 121]. Прежде всего, возникает вопрос: какая революция (Февральская или Октябрьская) завершена в России? На наш взгляд, ни та ни другая революции в России не завершены. Октябрьская революция не могла быть завершенной, т.к. модель государственного социализма через 70 лет после Октябрьской революции показала свою неконкурентность и потерпела крах. А Февральская революция не могла быть завершенной, т.к. в результате Октябрьской революции был осуществлен антидемократический переворот. В конце $80-\mathrm{X}$ - начале 90-х гг. XX в. произошла демократическая революция, которая привела ко второму после Февральской революции периоду демократизации, в ходе которого были частично восстановлены демократические институты, которые функционировали в период деятельности Временного правительства в 1917 г. (Государственная дума, многопартийность, свобода слова - в политической сфере, частная собственность, конкуренция в экономической).

Однако Конституция РФ 1993 г. закрепила навязанный вариант трансформации российского общества. В стране установится гибридный (авторитарнодемократический) политический режим. В этом плане трудно согласиться с позицией Е.М. Кожокина по вопросу оценки Конституции РФ 1993 г. Он считает, что «на референдуме была принята конституция, даровавшая огромные полномочия главе государства». И «эти полномочия фактически первый раз в истории России были четко конституционно определены» [Кожокин 2017: 121]. Как они могут быть «четко конституционно определены», если они не вписаны ни в одну из ветвей государственной власти? Не было четкости и при обсуждении и принятии Конституции РФ. Вместо Конституционного собрания проект Конституции обсуждался на конституционном совещании. А Конституция РФ была принята не на референдуме, а всенародным голосованием 12 декабря 1993 г.

И «в итоге политическая система нынешней России оказалась амбивалентной». И «с одной стороны, она вроде бы демократическая, так как ей присущи ключевые признаки демократического строя: всеобщие выборы, разделение властей, двухпалатный парламент, многопартийность, свобода прессы, глас- 
ность, комплекс гражданских прав, местное самоуправление». А «с другой - эти атрибуты демократии во многом декоративны, придавлены и “обесточены", поскольку Конституция РФ, принятая в 1993 году, закрепила общественный порядок, тяготеющий к самовластию» [Красин 2009: 27]. На наш взгляд, сказать, какая революция завершилась или продолжается в постсоветское время после принятия Конституции РФ в декабре 1993 г., весьма затруднительно. Конституция РФ 1993 г. не дает однозначного ответа на этот сложный вопрос.

Сама конституция носит противоречивый характер. В гл. 1 «Основы конституционного строя» сформулированы цели российского государства: «Россия есть демократическое федеративное правовое государство с республиканской формой правления» (ст. 1) и «Российская Федерация - социальное государство» (ст. 7), а также определяющий принцип демократического государства принцип разделения властей: «государственная власть в Российской Федерации осуществляется на основе разделения на законодательную, исполнительную и

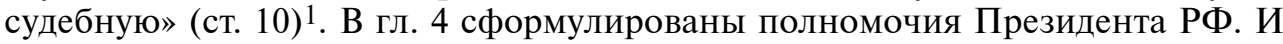
одним из важнейших является то, что «Президент Российской Федерации... обеспечивает согласованное функционирование и взаимодействие органов государственной власти» $\left(\right.$ ст. 80) ${ }^{2}$. Президент РФ не включен ни в одну из трех ветвей государственной власти. Статьи гл. 1 Конституции РФ носят демократический характер, а статьи гл. 4 - авторитарный. Гибридная конституция закрепляет гибридный политический режим - авторитарно-демократический. Содержание статей гл. 1 убеждает в том, что в РФ продолжается Февральская революция 1917 г. Цель совпадает - формирование демократического федеративного государства. Однако содержание статей гл. 4 напоминает о том, что продолжается и Октябрьская революция 1917 г. В главе сформулированы функции президентской формы самовластия как преемницы советской формы самовластия.

Следует отметить, что «самоопределение России, выбор вектора развития связан в первую очередь с трактовкой революции 1917 года - главного события российской истории ХХ столетия». Однако до сих пор в обществе, в экспертных кругах, среди историков нет единства... в оценке ее воздействия на российскую государственность и российский народ». А «солидарного взгляда на события такого масштаба быть не может по определению до тех пор, пока не станет солидарным нынешнее общество» [Комаровский 2017: 9-10]. Однако до такого состояния российскому обществу пока еще далековато. Социологические центры фиксируют значительный разброс оценок Октябрьской революции. По результатам опроса, проведенного в октябре 2017 г. ВЦИОМом, большинство респондентов оценивают последствия Октябрьской революции скорее положительно (38\% респондентов согласились, что «она дала толчок социальному и экономическому развитию страны», а $23 \%$ - что «она открыла новую эру в истории России»). При этом $13 \%$ опрошенных полагают, что «она стала для нашей страны катастрофой», а 14\% - что она «затормозила социально-экономическое развитие». А $12 \%$ респондентов затруднились с ответом ${ }^{3}$.

Также значительные расхождения обнаружил опрос, проведенный ЛевадаЦентром в марте 2017 г. Оценки роли Октябрьской революции в российской истории распределились следующим образом: «очень положительная» - $10 \%$, «скорее положительная» - 38\%, «скорее отрицательная» - 25\%, «крайне отрицательная» $-6 \%$, «затрудняюсь ответить» $-21 \%$. При этом $25 \%$ опрошенных

\footnotetext{
${ }_{1}^{1}$ Конституция Российской Федерации. М.: Норма. 2008. С. 2, 4, 6.

2 Там же. С. 42.

3 ВЦИОМ. Пресс-выпуск № 3488. 11.10.2017. Доступ: https://wciom.ru/index.php?id=236\&uid=116446 (проверено 12.08.2018).
} 
выразили согласие с тем, что «революция открыла новую эру в истории народов России», 36\% - что «она дала толчок их социальному и экономическому развитию», и только 6\% - с тем, что «что она стала для них катастрофой»1.

Следует отметить, что в нашей стране юбилей российских революций 1917 г. прошел удивительно тихо и незаметно. В течение юбилейного года идея «примирения и согласия» не раз фигурировала в выступлениях президента и других высоких должностных лиц. И «властвующая элита выбрала разумную тактику: ...уйдя от прямой полемики с оппонентами, она достигла своей цели - юбилей Октябрьской революции удалось провести мирно, без “разжигания страстей”». Однако «данные опросов общественного мнения и весьма скромный вклад юбилея в сложившуюся инфраструктуру памяти о революции (-ях) 1917 года заставляют предположить, что “примирения и согласия” по поводу этого события вряд ли удалось достичь» [Малинова 2018: 54-55].

А юбилей Февральской революции 1917 г. был отмечен в нашей стране еще более скромно, чем юбилей Октябрьской революции. Крупнейшие социологические центры России (ВЦИОМ, Левада-Центр) выявили в результате социологических опросов в 2017 г. отношение россиян только к Октябрьской революции. Но «понять Октябрь 17-го невозможно без осмысления другого ключевого события - Февральской революции 1917-го». И «если по справедливости, то эта историческая страница, которая долгое время была в пасынках у советской историографии, конечно, должна занять в нашей национальной памяти достойное место» [Миронов 2017].

По мнению А.Н. Медушевского, «Февральская революция 1917 года впервые в России выдвинула те идеи, которые реализовались в конце XX века или которые, по крайней мере, мы сейчас пытаемся реализовать» [Февральская революция... 2007: 5]. В.М. Лавров считает, что имеются общие и особенные черты Февральской революции в СССР и России в конце 1980-х - начале 1990-х гг. Разумеется, «мы могли говорить об общем и особенном в данных революциях» [Февральская революция... 2007: 5]. На наш взгляд, следует подчеркнуть общие черты, присущие Февральской революции 1917 г. и демократической революции в СССР и России в конце 1980-х - начале 1990-х гг. Во-первых, это были две попытки демократизации России в XX в. Во-вторых, Россия была провозглашена демократической республикой дважды: в сентябре 1917 г. и в декабре 1993 г. В-третьих, в ходе этих демократических революций были провозглашены свобода слова, собраний, вероисповедания.

В настоящее время существует возможность новой попытки демократизации российского общества. По мнению В.В. Петухова, «демократизация... будет представлять собой... пролонгированный во времени и осуществляемый под давлением гражданского общества процесс институциональных изменений, и изменения сознания граждан» [Петухов 2017: 21]. На наш взгляд, новая демократизация российского общества может быть осуществлена только при условии проведения конституционной реформы в РФ, направленной на реализацию в полном объеме принципа разделения государственной власти.

\section{Список литературы}

Кожокин Е.М. 2017. Закончилась ли Великая русская революция? - Полис. Политические исследования. № 6. С. 109-124.

Комаровский В.С. 2017. Наследие революции 1917 года в формировании идентичности современной России. - Власть. № 10. С. 7-15.

1 Левада-Центр. Пресс-выпуск. 05.04.2017. Доступ: https://www.levada.ru/2017/04/05/oktyabrskayarevolyutsiya-2/ (проверено 12.08.2018). 
Красин Ю.А. 2009. Метаморфозы российской реформации. М.: ИС РАН. 496 с.

Малинова О.Ю. 2018. Коммеморация столетия революции (й) 1917 года в РФ: сравнительный анализ соперничающих нарративов. - Полис. Политические исследования. № 2. С. 37-56.

Миронов С.М. 2017. Февраль - предвестник Октября. Доступ: https:// mironov-online.ru/media-publications/fevral-predvestnik-oktyabrya/ (проверено 12.08.2018).

Пантин И.К. 2015. Русская революция. Идеи, идеология, политическая практика. М.: Летний сад. 294 с.

Петухов В.В. 2017. Демократизация российского общества: возможна ли вторая попытка? - Полис. Политические исследования. № 5. С. 8-23.

Февральская революция 1917 года в российской истории: стенограмма круглого стола в ИРИ РАН. 15 марта 2007 г. Доступ: http://rus-istoria.ru/component/ k2/item/366-stenogramma-kruglogo-stola-fevralskaya-revolyutsiya-1917-g-vrossiyskoy-istorii-v-institute-rossiyskoy-istorii-ran-15-marta-2007-g (проверено 12.08.2018).

VORZHETSOV Aleksandr Grigorievich, Dr.Sci. (Philos.), Professor of the Chair of State, Municipal Administration and Sociology, Kazan National Research Technological University (68 Karla Marksa St, Kazan, Republic of Tatarstan, Russia, 420015; vag41@list.ru)

\section{HAVE THE REVOLUTIONS OF 1917 ENDED IN RUSSIA?}

Abstract. The article examines the consequences of February and October revolutions of 1917 in Russia, assesses the position of Russian scientists and politicians on the specifics of these revolutions. In the article the author tries to answer the debatable question: «Have the February and October Revolutions of 1917 in Russia ended?»

Keywords: February Revolution, October Revolution, democratic revolution in USSR and Russia in late 1980s and early 1990s, Constitution of Russian Federation, new democratization of Russian society 